\title{
Kidney Injury Molecule X (KIM-1): a Multifunctional Glycoprotein and Biological Mlarker (Review)
}

D01. $10.17691 / \mathrm{stm} 2021$ 13.3.08

Received August 21, 2020

T.A. Karmakova, DSc, Leading Researcher, Department of Predicting the Effectiveness of Conservative Therapy'; N.S. Sergeeva, DSc, Professor, Head of the Department of Predicting the Effectiveness of Conservative Therapy'; Professor, Department of Biology²;

K.Yu. Kanukoev, Urologist, Department of Urology with Chemotherapy ${ }^{1}$;

B.Ya. Alekseev, MD, DSc, Professor, Deputy General Director for Science ${ }^{3}$;

A.D. Kaprin, MD, DSc, Professor, Academician of the Russian Academy of Sciences, General Director ${ }^{3}$

${ }^{1} \mathrm{P}$. Hertsen Moscow Oncology Research Institute - Branch of the National Medical Research Radiological Centre of the Ministry of Health of the Russian Federation, 3, $2^{\text {nd }}$ Botkinsky Proezd, Moscow, 125284, Russia;

${ }^{2}$ Pirogov Russian National Research Medical University, 1 Ostrovitianova St., Moscow, 117997, Russia;

${ }^{3}$ National Medical Research Radiological Centre of the Ministry of Health of the Russian Federation, 4 Koroleva St., Obninsk, 249036, Russia

KIM-1 (kidney injury molecule 1) is a transmembrane glycoprotein also known as HAVcr-1 and TIM-1 belongs to the T-cell immunoglobulin and mucin domain family (TIM) of proteins. TIM glycoproteins are presented on the immune cells and participate in the regulation of immune reactions. KIM-1 differs from other members of its family in that it is expressed not only by immunocompetent cells but epithelial cells as well. Cellular and humoral effects mediated by KIM-1 are involved in a variety of physiological and pathophysiological processes.

Current understanding of the mechanisms determining the participation of KIM-1 in viral invasion, the immune response regulation, adaptive reactions of the kidney epithelium to acute ischemic or toxic injury, in progression of chronic renal diseases, and kidney cancer development have been presented in this review. Data of clinical researches demonstrating the association of KIM-1 with viral diseases and immune disorders have also been analyzed. Potential application of KIM-1 as urinary or serological marker in renal and cardiovascular diseases has been considered.

Key words: KIM-1; HAVcr-1; TIM-1; regulation of immune reactions; acute kidney injury; chronic renal failure; heart failure; renal cell carcinoma.

How to cite: Karmakova T.A., Sergeeva N.S., Kanukoev K.Yu., Alekseev B.Ya., Kaprin A.D. Kidney injury molecule 1 (KIM-1): a multifunctional glycoprotein and biological marker (review). Sovremennye tehnologii v medicine 2021; 13(3): 64, https://doi.org/10.17691/ stm2021.13.3.08

This is an open access article under the CC BY 4.0 license (https://creativecommons.org/licenses/by/4.0/).

\section{Introduction}

Biological markers are measurable molecular, biochemical, or structural indicators of the state of the cells, tissues, or organs which are currently used in practical medicine, preclinical, and experimental investigations owing to the development of biomedical technologies.
Not so long ago, membrane glycoprotein KIM-1, also known as HAVcr-1 and TIM-1, joined these markers.

In 1996, Kaplan et al. [1] were the first to describe mucin-like membrane glycoprotein type I homologous to the immunoglobulin family proteins which facilitated the penetration of the hepatitis A virus to the cultivated cells of the African green monkey kidney. This glycoprotein was called HAVcr-1 (hepatitis A virus cellular receptor 1).

Corresponding author: Tatyana A. Karmakova, e-mail: prognoz.06@mail.ru 
The DNA sequence homologous to havcr-1 was also detected in the human genome [1].

In 1998, Ichimura et al. [2], studying post-ischemic reparation of renal epithelium in rats, identified Kim-1 gene (kidney injury molecule 1), whose high expression was typical for epithelial cells of the damaged proximal renal tubules. This gene appeared to be a full homolog of HAVcr-1 [2].

In 2001, Mclntire et al. [3] found a gene cluster controlling hyperactivity of the respiratory epithelium (T-cell and airway phenotype regulator, Tapr) in mice resistant to the asthmatic reaction development. A group of genes included in this cluster was referred to a separate family, TIM (T-cell immunoglobulin and mucin domain family), called so due to the structural similarity of the encoded proteins. One of the genes, Tim-1, appeared to be a close homolog of Kim-1 in rats and HAVcr-1 in humans and primates [3]. Later, there were identified eight proteins, members of the TIM family (TIM-1, ., -8) in mice, six proteins (TIM-1, ., -6) in rats, three proteins TIM-1 (KIM-1), TIM-3, and TIM-4 in humans [4].

At present, HAVcr-1 gene bears its historical name in biological databases while in publications its product preserves the name commonly accepted in the appropriate field of investigation, i.e. HAVcr-1, KIM-1, or TIM-1 (CD365).

The TIM family glycoproteins are mostly expressed by the cells of the immune system and are involved in various physiological and pathological processes associated with the regulation of immune reactions [5]. KIM-1, unlike other members of the TIM family, is presented not only on lymphocytes but in other types of cells determining diverse manifestations of its functional activity.

The latest data on physiological and pathophysiological properties of HAVcr-1/KIM-1/TIM-1 have been systematized in the present review, some aspects of using this glycoprotein as a marker in clinical investigations have also been studied.

\section{KIM-1 molecule structure}

In the human genome, HAVcr-1 (Gene ID: 26762) is located on the long arm of chromosome 5 at locus $5 q 33.3$ and contains 11 exons. Variants of KIM-1 generated as a result of an alternative mRNA splicing may contain from 334 to 401 amino acids with variations of glycoprotein molecular mass from 36 to $44 \mathrm{kDa}$ [6, 7]. The molecular mass of a mature (fully glycosylated) $\mathrm{KIM}-1$ reaches $104 \mathrm{kDa}$ [6].

$\mathrm{KIM}-1$ is localized on the plasma membrane forming extracellular, transmembrane, and cytoplasmic domains (see the Figure) [8]. The extracellular part of KIM-1 includes a globular domain similar to the variable fragment of immunoglobulins (IgV), mucin-like sequence, and a short peptide segment.

A key feature of the $\mathrm{KIM}-1$ IgV-domain structure is the presence of a hydrophobic "pocket" (metal-iondependent ligand binding site, MILIBS), capable of binding a signaling phospholipid, phosphatidylserine (PS) [9]. Normally, PS is localized on the inner side of the cell plasma membrane and during apoptosis induction moves to the outer side of the membrane. It serves as a signal for macrophages and epithelial cells to absorb the dying cells [10]. It is believed that due to the ability to interact with PS, KIM-1 in the epithelial cells can perform the function of a scavenger receptor mediating in situ elimination of cellular debris in case of tissue damage [11]. Glycoproteins of the TIM family [12, 13], oxidized low-density lipoproteins [14], P-selectin [15], and conjugated blood bilirubin [16] are also potential ligands binding to which is mediated by lgV domain.

Highly glycosylated mucin-like domain, the most
Schematic structure of the TIM family glycoproteins (based on the materials of Kuchroo et al. [8])

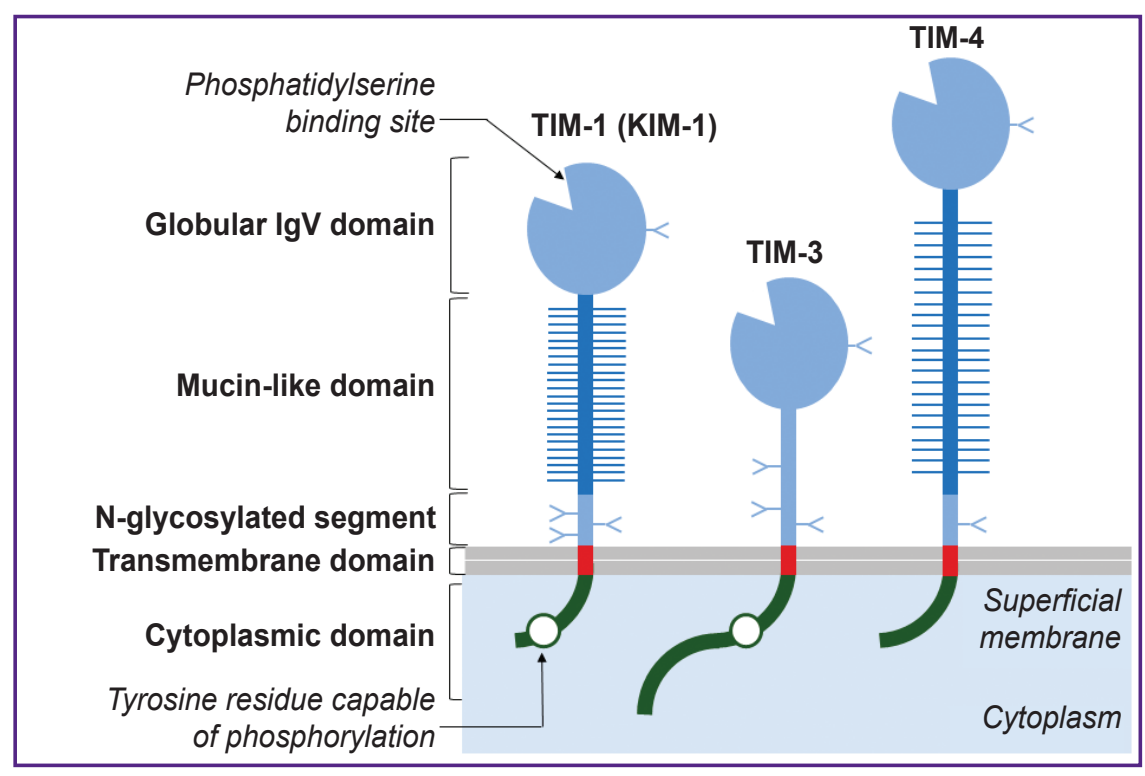


massive part of KIM-1, contains tandem repeats of amino acids and sites of O-glycosylation. No specific functional properties have been described for this domain; however, it is assumed that the organization of this molecular segment is important for the KIM-1 interaction with ligands $[8,17]$. In primates, this domain is characterized by a high genetically determined polymorphism [18].

A short peptide segment which is located immediately at the membrane contains $\mathrm{N}$-glycosylation sites and sequences sensitive to metalloproteinases. As a result of proteolytic cleavage, an extracellular part of $\mathrm{KIM}-1$ is shed from the cell surface and a free form of KIM-1 with molecular mass of about $90 \mathrm{kDa}$ is formed which can be identified in blood plasma and urine [6].

A KIM-1 cytoplasmic domain is a variable short polypeptide differentiated in the structural KIM-1 variants [6]. In renal epithelium and lymphocytes, this domain is capable of phosphorylation which determines the possibility of involving $\mathrm{KIM}-1$ in intracellular signaling $[6,17]$.

\section{KIM-1 expression in tissues}

In normal human tissues, expression of mRNA encoding the HAVcr-1 protein is characterized by marked organ specificity [19]. The greatest amount of HAVcr-1 transcripts was found in the kidney tissue, less but significant - in the testicle tissue. In other tissues, specific transcripts were identified in trace quantities. Current data obtained by deep transcriptome sequencing confirm that content of HAVcr-1 transcripts in the kidney is 10 times higher than in the majority of other organs and tissues [7]. Significant amounts of HAVcr-1 mRNA are detected in the tissue of the colon and rectum, testes, and also in peripheral blood leukocytes [7].

Immunological studies using polyclonal antibodies to the recombinant $\mathrm{HAVcr}-1$ demonstrate weak or moderate cytoplasmic staining in the cells of kidney tubule epithelium and urothelium, in the glands of the small and large intestine, epithelium of the liver bile ducts and gall bladder, bronchial epithelium, endometrium, etc. [7]. Additionally, HAVcr-1 is detected in oligodendrocytes of the human brain and myocytes of the skeletal muscle tissue. Thus, HAVcr-1 is expressed practically in all human organs and tissues but normally the level of its expression is low.

\section{KIM-1 and viral infection}

TIM family glycoproteins may serve as a site of entry for viral infection due to the fact that enveloped and pseudo-enveloped viruses use the ability of IgV-domain to bind PS to penetrate the cell [20]. Virus particles released from the dying cells trap the fragments of the host cell surface membrane containing PS (apoptotic mimicry) [21]. PS contained within the viral envelope interacts with TIM-1 molecules on the surface of other target cells promoting the attachment of virions and facilitating their internalization [20].

TIM-1 has been shown to mediate the penetration of hepatitis $A$ and $C$ viruses, human immunodeficiency virus (HIV), Ebola, Marburg and dengue viruses, Japanese encephalitis virus into the cells [20]. The effect of TIM-1 on the pathogenesis of viral diseases is confirmed by the fact that some of its polymorphisms are associated with susceptibility or, on the contrary, resistance to HIV infection [22], filoviral infection [23], viral hepatitis agents $[24,25]$. It has been established in the experimental studies that "a cytokine storm", a massive release of proinflammatory mediators, which occurs in Ebola virus infection, is induced in PS-mediated interaction of the virus with TIM-1 on the surface of T-lymphocytes. PS blockage decreases binding of the virus to the cells in vitro while the TIM-1-knockout mice survive when fatally infected by the virus [26].

At the same time, the role of TIM-1 in the development of, for example, HIV, is ambiguous: on the one hand, TIM-1 expression enhances virus internalization, on the other, the same TIM-1 inhibits the release of viral particles from the cell by binding and accumulating viral agglomerates at the cell surface, i.e. turns the cell to a "trap" for the virus [27].

A high polymorphism of the HAVcr-1 gene in primates is supposed by the investigators to be the result of evolutionary divergence of the mechanisms of adaptation to viral infections and allergic reactions in mammals [18].

\section{KIM-1 and immune reactions}

KIM-1/TIM-1, presented on lymphocytes, participates in the formation of both immunostimulating and immunosuppressive reactions. The character of immune TIM-1-mediated effects depends on the cells carrying it, interacting ligands, and their concentration as well as on the cellular microenvironment [12, 17, 28]. Realization of immune reactions in which TIM-1 is involved is influenced by a cooperative participation of other glycoproteins of the TIM family. TIM-4 in this case is a co-stimulating factor in cell interactions, while TIM-3 is an instrument of reciprocal regulation of the TIM-1related reactions of the innate and acquired immune response [29].

TIM-1 has been established to be involved in the regulation of the T-cell immunity determining the differentiation and clonal expansion of T-helpers and corresponding polarization of the immune response in the direction of the predominance of Th2-, Th1-, or Th17mediated effects [30]. TIM-1 activation by its agonists results in the development of the rapid proinflammatory response in vitro and in vivo [31, 32].

TIM-1 is closely related to the formation of the TCRcomplex which is responsible for the recognition of antigens presented by the molecules of the major histocompatibility complex on T-lymphocytes [33]. In 
the naive lymphocytes, TIM-1 is mainly contained in endosomes, and under the activating stimulus, it is transported to the cell surface and concentrates in the region of the immune synapse [34]. Phosphorylation of the cytoplasmic TIM-1 domain in the TRC-complex is part of activation of PI3K/AKT signaling pathway cascade [35]. Ligands interacting with high affinity with TIM-1, for example, PS, bind glycoprotein exposed on the superficial membrane and therefore may reduce its contribution to the T-cell activation [34].

Interacting with P-selectin, TIM-1 is able to participate in the processes of adhesion and leukocyte movement in inflammatory response [36]. Acting as a PS receptor, TIM-1 promotes phagocytosis of apoptotic cells by macrophages, which inhibits autoimmune reactions [9] and activates invariant NKT cells as well [31].

Most information on the role of TIM-1 in the regulation of immune reactions was obtained from the investigations on animals (mice). However, regulation and functions of TIM-1 in rodents and primates are likely to differ essentially [33]. So, locus Tapr in mice contains 8 genes. Five of them are absent in humans including Tim-2 gene coding glycoprotein which acts as an inhibitor of TIM-1-mediated signaling. Besides, proteins of TIM family are able to bind various natural ligands [30], therefore, it is next to impossible to anticipate the integral result of these interactions in the model studies.

The role of TIM-1 in the regulation of immune reactions in a human is indirectly confirmed by the fact that genetic TIM-1 polymorphisms in some ethnic populations are associated with bronchial asthma [3740] and systemic lupus erythematosus [41], correlate with the inflammatory reaction intensity, and the severity of community-acquired pneumonia in children [42].

The greatest interest to TIM-1 in immunological studies is connected with its role in the physiology of regulatory cells. It has been shown that the interaction of TIM-1 with the antagonist ligands is a stimulating factor for suppressor T-regulatory cells (Treg) [43]. The reduced TIM-1 expression on the Treg cells is noted in patients with diabetes mellitus type I [44]. TIM-1 expression is typical for one of the regulatory B cells (Breg) subpopulations producing IL-10, the main negative regulator of the inflammatory response [45, 46]. In the clinical studies, there has been revealed the correlation between a high content of TIM-1 positive $\left(\mathrm{TIM}-1^{+}\right) \mathrm{B}$ cells in peripheral blood and a favorable prognosis in patients with acute respiratory distress syndrome [47]. Decreased amount of TIM-1 $1^{+}$Breg cells in peripheral blood is noted in patients with progressive systemic sclerosis in comparison with healthy donors [48]. An elevated TIM-1 expression on Breg cells correlating with the disease severity is described in myasthenia gravis [49].

$\mathrm{TIM}-1^{+}$Breg cells attract special attention due to their probable participation in the suppression of antitumor immune reactions. Thus, in patients with hepatocellular carcinoma, a relative content of $\mathrm{TIM}-1^{+} \mathrm{B}$ cells in peripheral blood and in tumor tissue is statistically significantly higher than in healthy donors and in nontumor liver tissue, respectively $[50,51]$. Similar tendency was revealed in lung cancer [51]. The degree of infiltration of hepatic carcinoma tissue by $\mathrm{TIM}-1^{+} \mathrm{B}$ cells directly correlates with the disease stage and early tumor recurrence after surgical treatment [51].

On the whole, TIM-1 today ranks among the critical immune checkpoints which may serve as targets for therapeutic action aimed, inter alia, at the activation of antitumor immune reactions [52-54].

\section{KIM-1 in acute kidney injury}

Acute kidney injury (AKI) may be the result of shock condition and acute cardiovascular insufficiency, toxic or septic injury, urinary duct obstruction [55]. The most common AKI cause is ischemia [56] leading to the death and exfoliation of tubular epithelial cells from the basement membrane. AKI is a potentially reversible disorder since kidney tubule epithelium possesses high regeneration ability. The cells with preserved viability undergo epithelial-mesenchymal transition, proliferate, and migrate to the areas of the exposed basement membrane where they return to the differentiated epithelial phenotype [57].

It was shown in various AKI models in rats that KIM-1 expression on the apical surface of the epithelial cells of the renal proximal tubules is induced by ischemia and toxic damage [2, 58]. Ichimura et al. [2] were the first to suppose that this phenomenon is associated with the processes of renal epithelium regeneration. Later, Zhang et al. [59] established a direct relationship between the increased KIM-1 expression in the tissue of the transplanted kidney and its functional restoration. Thus, the increase of KIM-1 production in the proximal tubular cells in AKI is likely to be an adaptive response, being not only the marker of injury but the reflection of the reparation activity [59].

Investigations on animals and cell cultures show that in AKI KIM-1 is directly involved in the processes of preservation and restoration of the structural and functional integrity of the epithelium of proximal nephron compartments [14, 60]. It is supposed that possessing the features of PS, KIM-1 may induce phagocytosis of dying cell residues maintaining thereby cleaning of the proximal tubular lumen from cellular debris and decreasing the probability of filtrate flow impairment [14]. Increase of $\mathrm{KIM}-1$ expression on the surface of the proximal tubular epithelial cells is induced by the presence of albumin in the glomerular filtrate [61]. In this case, KIM-1 can capture albumin from the primary urine, carry it into the cell which supplements the main receptor mechanisms of protein reabsorption in the kidneys in severe proteinuria [61].

An elevated $\mathrm{KIM}-1$ expression in the renal proximal tubular cells inhibits proliferation and activity of 
effector $\mathrm{T}$ cells and leads to the increase of Treg cell content in the kidney tissue providing local formation of immune tolerance conditions and prevents the development of autoimmune reactions [60]. Entrapment of apoptotic bodies by the renal epithelial cells induces interaction of cytoplasmic domain $\mathrm{KIM}-1$ with protein p85. This stimulates autophagia and inhibits the activity of transcription factor NFkB responsible for the proinflammatory cytokine production by the cell $[60$, 62]. Besides, the cytoplasmic domain $\mathrm{KIM}-1$ is able to influence the $G$ protein activity, pleiotropic regulator of intracellular signaling processes, reducing the probability of cell damage in ischemia and hypoxia [63]. Increased $\mathrm{KIM}-1$ production can result in the reduced intracellular content of nuclear receptor Nur77, an inductor of apoptosis, preventing the programmed cell death and enhancing their survivability in stress conditions [64]. KIM-1 expression has also been shown to promote migration and proliferation of dedifferentiated cells in the regenerating renal epithelium [65].

Proteolytic cleavage of the extracellular domain $\mathrm{KIM}-1$, which occurs normally in the renal epithelial cells, determines the basic level of glycoprotein in urine. This process is enhanced many times when cells are damaged. Presence of serum albumin, production of TNF- $\alpha$ by immune cells, and active forms of oxygen may serve as stimuli for the enhancement of KIM-1 cleavage [66]. A free KIM-1 form has been shown to interact with integrin on the apical cell surface which may prevent aggregation of the cleaved cells and diminish the risk of tubule obstruction [67].

When renal epithelial cells die, a soluble KIM-1 together with the fluid may be entrained to the interstitium and enter therefrom the bloodstream [68]. Higher KIM-1 concentration in blood together with its increased contents in urine can also reflect injury of the kidney tubular apparatus [69].

KIM-1 possesses the properties of ideal marker of renal proximal tubule epithelium injury [70]: in the normal kidney, KIM-1 expression is determined in trace quantities; in ischemic or toxic kidney injury, activation of $\mathrm{KIM}-1$ synthesis in the cells of the damaged tubules and its increased expression on the apical cell membrane is observed; shedding of KIM-1 from the cell surface results in considerable increase of its content in urine and/or in the circulating blood. According to the data of the experimental studies on animals, KIM-1 expression in the epithelial cells of the renal proximal tubules as well as its concentration in urine and blood plasma correlate with the severity of the pathological process in the kidneys [70]. Elevation of KIM-1 level in urine (uKIM-1) is a more sensitive indicator of AKI than the reduction of creatinine clearance or albuminuria. It is underlined that enhanced excretion of $\mathrm{KIM}-1$ in urine is highly specific for the conditions caused by kidney injury since, due to a large molecular mass, free KIM-1 entering the blood from extrarenal sources, is not filtered through the glomerular barrier. Moreover, no other body tissue produces KIM-1 in the quantities capable of essential influence on its content in urine [70].

In 2010, FDA (US Food and Drug Administration), and EMEA (European Medicines Agency) included uKIM-1 into the number of the markers of drug nephrotoxicity for preclinical trials [71]. This was the impetus for widening the sphere of studying uKIM-1 and its content in blood plasma and serum (pKIM-1 or sKIM-1) [72]. According to the data of meta-analysis summarizing the results of clinical investigations carried out from 2008 to 2013, sensitivity and specificity of UKIM-1 as a predictor of AKI development were 81.8 and $83.8 \%$, respectively [73]. KIM-1 as a marker of kidney injury appeared to be promising in translational research in rodents [69, 74], dogs [75], cats [76], and Danio rerio (zebrafish) [77].

Numerous publications give convincing evidence that the increased uKIM-1 level is a reliable indicator of drug therapy nephrotoxicity. It is known that application of anticancer medication (chemotherapy) can not only cause AKI but also provoke chronic renal disease [78]. Urea nitrogen concentration and creatinine clearance, which characterize nephron filtration activity, are considered to be classic indicators of drug-induced nephrotoxicity. However, administration of cisplatin, doxorubicin, or methotrexate does not result in serious impairment of the renal glomerular function but the main damage is observed in the proximal tubular epithelium which accumulates these preparations to the greatest degree [79]. According to quite a number of clinical studies [ 80,81$],$ UKIM-1 is a highly sensitive and specific marker of nephrotoxicity induced by cisplatin and is superior in this respect to other urinary markers both classic and new.

In HIV carriers receiving antiretroviral therapy, determination of uKIM-1 level is recognized advisable for diagnosing renal function disorder, predicting progression of renal insufficiency, and the related risk of lethal outcome [82]. Increase of uKIM-1 has been established in AKI caused by treatment with vancomycin [83], adefovir [84], and paracetamol overdosage [85].

Findings of several studies have shown that uKIM-1 is an early marker of $\mathrm{AKI}$ induced by the administration of the contrast agent to the patients who undergo coronary or peripheral angiography $[86,87]$, and pKIM-1 may serve as a prognostic marker of concurrent chronic kidney injury development [88].

Of special interest are data on the possibility of using uKIM-1 as a noninvasive marker for the assessment of functional state of the transplanted kidney [89]. Inevitable ischemia during organ transplantation results in the renal tissue injury to various degree which is accompanied by the increased KIM-1 expression in the epithelial cells of the renal proximal tubules. The analysis of biopsy specimens found direct correlation between KIM-1 expression in the kidney allograft tissue and fibrosis [90] and inverse correlation with tubular epithelium condition [91]. Increased uKIM-1 and SKIM-1 have been shown to accompany acute or delayed allograft rejection [92] and 
to occur several months earlier than the clinical signs of acute renal dysfunction [93].

There exist data indicating that uKIM-1 correlates with the AKI development in sepsis [94], and sKIM-1 elevation is a predictor of exacerbation of urinary tract infections in children [95]. In congenital ureteral stricture in children, identification of UKIM-1 in combination with urinary NGAL and RBP may be useful for the monitoring of kidney condition and in making a decision on the necessity of surgical intervention [96].

\section{$\mathrm{KIM}-1$ in chronic kidney diseases}

Chronic kidney disease (CKD) is a natural outcome of the majority of nephropathies and can be provoked by acute and recurrent kidney injury of various etiologies [97]. The main pathogenetic mechanism of progressive CKD is the condition of chronic hypoxia which occurs due to structural and functional disorders in the network of post-glomerular capillaries, excessive activity of renin-angiotensin system, compensatory increase of oxygen consumption by the renal tissue cells under the condition of deterioration in glomerular function and oxidative stress [98]. Chronic hypoxia leads to sclerotic glomerular changes and tubulointerstitial fibrosis [98]. Besides, it is supposed that in CKD, an important role in the development of these disorders is played by the acquisition of mesenchymal phenotype by the cells of the damaged proximal tubules and the release of profibrotic factors by them [99].

Hypoxia is a powerful stimulus of KIM-1 expression increase in proximal tubular cells which, in its turn, may result in the induction of chronic interstitial inflammation $[89,100]$. Membrane-bound as well as free KIM-1 are considered to be involved in signaling interactions between the cells of the damaged renal proximal tubules and macrophages acting as autocrine-paracrine factor in relation to the epithelial and stromal cells $[62,66,101]$. In particular, interaction of KIM-1 with LMIR5/CD300b receptor on the resident myeloid cells has been shown to lead to the release of cytokines and chemokines which attract neutrophils to the focus of injury. This provokes enhancement of local inflammatory reactions, hypoxia, and cell damage [102]. Elevated KIM-1 expression under hypoxic conditions promotes CKD progression creating a positive feedback loop which is completed with interstitial fibrosis [103]. Thus, functional KIM-1 effects may be a connecting mechanism in the pathogenesis of acute and chronic renal disorders.

Increase of KIM-1 expression and an elevated uKIM-1 level are described in focal glomerulosclerosis, proliferative and membrane glomerulonephritis, IgA nephropathy, diabetic and hypertensive nephropathy, chronic allograft nephropathy, lupus nephritis, etc. [89]. However, the prognostic significance of uKIM-1 in CKD seems to be limited [104, 105]. Seibert et al. [106] did not find reliable link between UKIM-1 and indicators of kidney function in patients with chronic diseases and associate it with the fact that in the majority of patients enrolled in the study such diseases were caused by the preferential damage of the glomerular apparatus. At the same time, the authors note that in IgA nephropathy, membranous and lupus nephritis, uKIM-1 inversely correlates with the glomerular filtration rate, i.e. in some chronic renal inflammatory lesions, uKIM-1 may pretend to the role of a biological marker [106]. Data on the correlation of uKIM-1 with the severity of $\lg A$ nephropathy [107], tubular atrophy, and tubulointerstitial inflammation in patients with systemic lupus erythematosus [108], activity of chronic glomerulonephritis, and efficacy of treatment of this disease agree with this conclusion [109, 110].

The analysis of data from five cohort prospective studies, included patients with atherosclerosis, diabetes, chronic kidney diseases, as well as elderly people referred to the conventional group of risk, has shown that increased UKIM-1 correlates with the reduction of glomerular filtration rate, albuminuria, and the risk of chronic renal failure development which confirms close interrelation between glomerular and tubular dysfunction [111].

Findings of clinical investigations [112] demonstrate that the uKIM-1 level rises in diabetic nephropathy including patients with normal or slightly increased albumin in urine. However, uKIM-1 is likely to have no essential preference as a marker of kidney injury in diabetic patients in comparison with the traditional laboratory parameters [113].

It should be noted that the increased KIM-1 level in blood in CKD may have a greater clinical significance than its content growth in urine. Thus, in patients with diabetes mellitus type I, rise of KIM-1 levels in blood correlates with the reduction of glomerular filtration rate allowing this glycoprotein to be considered as an early marker of renal failure progression [69, 114].

\section{$\mathrm{KIM}-1$ in cardiovascular diseases}

Physiological interconnection between the activity of kidneys, heart, and vessels creates the situation when dysfunction of either of these systems aggravates disorders in the entire cardiorenal continuum [115]. Searching for new predictive markers of cardiovascular diseases showed that pKIM-1 reflects the severity of the state for patients with heart failure [116]. In elderly diabetic men, uKIM-1 growth is associated with the risk of death from cardiovascular complications irrespective of other indicators [117]. Egli et al. [118] during clinical examination of 2060 conditionally healthy people at the age of 25-41 years have revealed that pKIM-1 levels do not correlate with the indices of renal function impairment (creatinine and cystatin C) in this population but is statistically significantly associated with the risk factors of cardiovascular diseases: high arterial pressure, blood content of low- and high-density lipoproteins as well as C-reactive protein. 


\section{REVIEWS}

Wybraniec et al. [119] have followed-up 95 patients after coronary angiography for 12 months and established that the uKIM-1 levels increase after this diagnostic procedure is an independent predictor of infarction or stroke for these patients in the remote period.

Some investigators believe that the elevated UKIM-1 levels may serve as an early diagnostic indicator of AKI in patients after cardiac surgery [73] and correlate with the length of acute period of renal disorders [120]. According to other data [121, 122], uKIM-1 is low informative to assess the development of renal complications in patients after heart surgery, but its increase is associated with a lethal outcome. A more accurate prognostic assessment may be obtained combining uKIM-1 with other markers of kidney injury, i.e. NGAL in blood plasma and IL-18 in urine [121], or cysteine $C$ in blood serum and NGAL in urine [122]. It has been shown that in patients with heart failure or atherosclerosis, uKIM-1 in combination with cysteine $\mathrm{C}$ may serve as an early marker of AKI [123] and a risk factor of renal failure progression up to the terminal stage [124], and prognostic significance of UKIM-1 within the frames of such assessment exceeds other urinary markers of renal injury (NAG, NGAL, and L-FABP) [125].

\section{$\mathrm{KIM}-1$ in renal cancer}

Renal cell carcinoma (RCC) is a malignant neoplasm originated from the renal tubular epithelium. The majority of cases of primary sporadic RCC are tumors derived from the cells of the renal proximal tubules: clear cell RCC (75-92\%) and papillary RCC (4-16\%) [126, 127]. Chromophobe RCC occurs not so commonly $(2.4-5.0 \%)$ $[126,127]$, it is thought to develop from the epithelium of the distal nephron parts.

Immunohistochemical evaluations show that an elevated KIM-1 expression in clear cell carcinoma is observed in $71-100 \%$ cases, in papillary RCC in $80-91 \%$ cases [128-131]. A relatively high rate of KIM-1 expression (74\%) was found in the tissues of nephroblastoma in children [132]. KIM-1 is determined extremely rarely in the cells of chromophobe RCC as well as benign oncocytomas [128, 131].

$\mathrm{KIM}-1$ is supposed to play a functional role in the pathogenesis of renal carcinomas and disease progression. According to the data of in vitro studies, $\mathrm{KIM}-1$ expression in the human umbilical vein endothelial cells (HUVEC) transfected by HAVcr-1 increases their disintegration and sensitivity to the action of hepatocyte growth factor destroying intercellular contacts [133]. KIM-1 has been detected [134] to interact with Rho GTPase which regulates the dynamics of the assembly of cytoplasmic ZO-protein complex supporting the structure of the tight junctions. This can promote disintegration of the tumor cells and facilitate metastasizing.

TIM-1-mediated regulation of the nuclear receptor
Nur77 degradation results in the inhibition of apoptosis signals in the cells of human renal carcinoma and immortalized cells of the renal epithelium [64]. This mechanism which maintains the integrity of the renal tubular epithelium in ischemic injury may contribute to the survival of the tumor cells.

IL-6 is known to be a key factor of tumor-associated inflammation, while co-expression of IL-6 and its receptor in the RCC tissue are associated with a poor prognosis in renal carcinoma patients [135]. Cuadros et al. [136] report that overexpression of KIM-1 in the carcinoma cells in vitro correlates with the greater activity of their proliferation and increased IL-6 production. The induction of $\mathrm{IL}-6$ expression directly depended on the intensity of $\mathrm{KIM}-1$ shedding from the tumor cell surfaces. The authors believe that a free extracellular domain $\mathrm{KIM}-1$ is capable of activating the signaling axis KIM-1/IL-6/STAT-3 via the paracrine or autocrine mechanism.

Irrespective of the KIM-1 expression level in the tumor cells, its increased synthesis is observed in the epithelium of the renal proximal tubular cells in the unchanged kidney tissue surrounding malignant tumor. It may be a consequence of the tissue compression and ischemia caused by progressive growth of the neoplasm [128]. However, Cuadros et al. [130] came to a conclusion that in the clear cell renal carcinoma, the elevated $\mathrm{KIM}-1$ expression in the morphologically normal adjacent tissue does not depend on the tumor growth and reflects most likely individual predisposition to RCC development.

As have already been mentioned, increase of KIM-1 expression in chronic hypoxia can maintain low-grade inflammation, and the shed extracellular KIM-1 domain is able to interact with the tumor stroma components, i.e. endothelial cells, tumor-associated myeloid cells, and lymphocytes. Interstitial inflammation serves as a source of growth factors and cytokines stimulating proliferation of cancer cells and neoangiogenesis and also attracts lymphoid and myeloid suppressor cells leading to the suppression of the innate and acquired immunity, inhibition of cytotoxic lymphocyte activity [137]. Thus, aberrant KIM-1 expression in RCC cells and/or in the renal tubular epithelium in the tissue surrounding the tumor can make a definite contribution to the formation of tolerant microenvironment and to the escape of cancer cells from immune surveillance.

Increased KIM-1 expression in the renal tissue in $\mathrm{RCC}$ is accompanied by its greater content in urine and blood plasma [128, 130, 131, 138-140]. Concentration of uKIM-1 in RCC patients exceeds statistically significantly that in healthy individuals, and elevation of the uKIM-1 levels correlates with the disease stage, tumor size, and tumor grade [130, 138, 140]. After nephrectomy, uKIM-1 concentration reduces and approximates normal values $[131,138,140]$, which points to the tumor as a direct source of KIM-1 in the patients' urine.

Zhang et al. [131] note a direct correlation between 
UKIM-1 and the level of KIM-1 expression in the RCC cells. According to other studies [128, 141], increased uKIM-1 levels are also observed in chromophobe RCC which is not typically express KIM-1. The source of the elevated uKIM-1 in these cases is likely to be the altered renal parenchyma rather than the cancer cells [128].

In patients with clear cell or papillary RCC, statistically significant increase of KIM-1 concentration in blood plasma is observed relative to healthy donors. pKIM-1 levels in these patients correlate with the cancer stage while in patients with chromophobe RCC, pKIM-1 does not practically differ from that in healthy individuals [142]. According to the data of the multicenter prospective cohort study EPIC (European Prospective Investigation into Cancer and Nutrition), the increase of the pKIM-1 level may serve as a predictor of the RCC risk: in the group of individuals with the revealed RCC during diagnostic monitoring, an average pKIM-1 level in the previous years was 2.5 times higher than in healthy donors [143]. The authors believe that increased pKIM-1 without specific symptoms increases 63 times the probability of malignant neoplasm development in the kidneys during the following 5 years.

\section{$\mathrm{KIM}-1$ in malignant tumors}

of extra-renal localization

KIM-1 overexpression in the cells of clear cell and papillary RCC has for a long time been considered as a unique feature of kidney tumors. Performing immunohistochemical staining of 484 specimens of tumors of extra-renal origin using monoclonal antibody AKG7, Han et al. [128] did not reveal KIM-1 expression in most cases. These data are quite in line with the assessment of $\mathrm{KIM}-1$ mRNA expression: the content of HAVcr-1 transcripts in the renal malignant tissues is 10 times higher than that in malignant tumors of other localization [7].

Later, KIM-1 expression was described in clear cell carcinoma of the ovary $(93.8 \%)$ and endometrium $(33.3 \%)$, in colon carcinoma $(12.5 \%)$ [129], germ cell tumors $(50 \%)$ [144], as well as in the cells of primary lymphoma of the central nervous system (54\%) [145].

According to the data obtained from the Human Protein Atlas database [7], a high intensity staining the tumor cells with anti-HAVcr-1 polyclonal antibodies was detected in breast and stomach cancer, a weak or moderate intensity was revealed in colon cancer, pancreas, non-small cell lung cancer, and ovarian carcinoma. Disagreement in the assessment of the HAVcr-1/KIM-1/TIM-1 expression in cancer tissues may be explained by different sensitivity of the immunochemical methods or unique epitope specificity of AKG7 antibody [59].

Data on clinical significance of increased KIM-1 expression in the tumors of extra-renal localization are ambiguous. Thus, in stomach cancer, an elevated expression of $\mathrm{KIM}-1$ mRNA is associated with unfavorable prognosis and low sensitivity to chemotherapy [146]. HAVcr-1 knockdown reduces the activity of proliferation and colony formation, migration, and invasion of gastric cancer cells in vitro [147]. In non-small cell lung cancer, increased KIM-1 expression at the level of protein and mRNA is also associated with a worse patients' survival [148]. Inactivation of KIM-1 in A549 and SK-MES-1 lung cancer cells suppresses proliferation, migration activity, and invasion and is also accompanied by the rise of the level of tumor suppressor protein PTEN and inhibition of prooncogenic PI3K/Akt signaling pathway [148]. At the same time, overexpression of $\mathrm{KIM}-1$ mRNA in the colon cancer tissue is associated, on the contrary, with a longer recurrence-free survival of patients [149]. Transfection of the colon cancer cells with $H A V c r-1$ gene does not influence the growth rate and cell motility in vitro but reduces their invasion ability [149].

No correlation has been found between the level of KIM-1 expression in the cancer cells and clinical and morphological characteristics of the mentioned malignant diseases, which indicates independent prognostic significance of this indicator.

\section{Conclusion}

The accumulated store of knowledge forms today the notion on HAVcr-1/KIM-1/TIM-1 as a multifunctional evolutionally conservative molecule resembling twofaced Janus. On the one hand, KIM-1 is involved in homeostasis maintenance participating in the regulation of immune reactions and supporting functional state of renal tubular epithelium in case of ischemic and toxic stress. On the other hand, $\mathrm{KIM}-1$ is used by highly pathogenic viruses for penetration into the cells. Its long expression in the proximal tubular cells in kidneys promotes the development of fibrotic changes while increased expression in the cells of RCC and some other malignant tumors may be the factor provoking tumor progression. Molecular mechanisms determining the role of KIM-1 in normal and pathological conditions and the meanings of these processes still are waiting for deep exploration. Nevertheless, predicting properties of $\mathrm{KIM}-1$ as an urinary and serologic marker in some kinds of acute and chronic kidney injury, renal cell carcinoma, cardiovascular diseases may already be used in the current clinical practice.

Authors' contributions: T.A. Karmakova analyzed scientific information on molecular biological and immunological aspects of the problem, wrote appropriate sections for the manuscript; N.S. Sergeeva worked out the conception and design of the review, analyzed scientific information on medico-biological aspects, wrote appropriate sections of the manuscript; K.Yu. Kanukoev analyzed scientific information on clinical aspects of the problem, wrote appropriate sections of the manuscript; 
B.Ya. Alekseev was responsible for critical analysis and revision of the clinical sections; A.D. Kaprin was involved in the critical analysis of the manuscript and introduction of a valuable intellectual content.

Research funding. The work was not supported by any financial source.

Conflicts of interest. The authors have no conflicts of interest to declare.

\section{References}

1. Kaplan G., Totsuka A., Thompson P., Akatsuka T., Moritsugu Y., Feinstone S.M. Identification of a surface glycoprotein on African green monkey kidney cells as a receptor for hepatitis A virus. EMBO J 1996; 15(16): 4282-4296.

2. Ichimura T., Bonventre J.V., Bailly V., Wei H., Hession C.A., Cate R.L., Sanicola M. Kidney injury molecule-1 (KIM-1), a putative epithelial cell adhesion molecule containing a novel immunoglobulin domain, is up-regulated in renal cells after injury. J Biol Chem 1998; 273(7): 4135-4142, https://doi. org/10.1074/jbc.273.7.4135.

3. McIntire J.J., Umetsu S.E., Akbari O., Potter M., Kuchroo V.K., Barsh G.S., Freeman G.J., Umetsu D.T., DeKruyff R.H. Identification of Tapr (an airway hyperreactivity regulatory locus) and the linked Tim gene family. Nat Immunol 2001; 2(12): 1109-1116, https://doi.org/10.1038/ni739.

4. Kuchroo V.K., Meyers J.H., Umetsu D.T., DeKruyff R.H. TIM family of genes in immunity and tolerance. Adv Immunol 2006; 91: 227-249, https://doi.org/10.1016/s00652776(06)91006-2.

5. Li Z., Ju Z., Frieri M. The T-cell immunoglobulin and mucin domain (Tim) gene family in asthma, allergy, and autoimmunity. Allergy Asthma Proc 2013; 34(1): e21-e26, https://doi.org/10.2500/aap.2013.34.3646.

6. Bailly V., Zhang Z., Meier W., Cate R., Sanicola M., Bonventre J.V. Shedding of kidney injury molecule-1, a putative adhesion protein involved in renal regeneration. J Biol Chem 2002; 277(42): 39739-39748, https://doi.org/10.1074/ jbc.m200562200.

7. The Human Protein Atlas. HAVCR1. URL: https://www. proteinatlas.org/ensg00000113249-havcr1.

8. Kuchroo V.K., Umetsu D.T., DeKruyff R.H., Freeman G.J. The TIM gene family: emerging roles in immunity and disease. Nat Rev Immunol 2003; 3(6): 454-462, https:// doi.org/10.1038/nri1111.

9. Kobayashi N., Karisola P., Peña-Cruz V., Dorfman D.M., Jinushi M., Umetsu S.E., Butte M.J., Nagumo H., Chernova I., Zhu B., Sharpe A.H., Ito S., Dranoff G., Kaplan G.G., Casasnovas J.M., Umetsu D.T., DeKruyff R.H., Freeman G.J. TIM-1 and TIM-4 glycoproteins bind phosphatidylserine and mediate uptake of apoptotic cells. Immunity 2007; 27(6): 927-940, https://doi. org/10.1016/j.immuni.2007.11.011.

10. Günther J., Seyfert H.M. The first line of defence: insights into mechanisms and relevance of phagocytosis in epithelial cells. Semin Immunopathol 2018; 40(6): 555-565, https://doi.org/10.1007/s00281-018-0701-1.

11. DeKruyff R.H., Bu X., Ballesteros A., Santiago C., Chim Y.L., Lee H.H., Karisola P., Pichavant M., Kaplan G.G., Umetsu D.T., Freeman G.J., Casasnovas J.M. T cell/ transmembrane, Ig, and mucin-3 allelic variants differentially recognize phosphatidylserine and mediate phagocytosis of apoptotic cells. J Immunol 2010; 184(4): 1918-1930, https:// doi.org/10.4049/jimmunol.0903059.

12. Meyers J.H., Chakravarti S., Schlesinger D., Illes Z., Waldner H., Umetsu S.E., Kenny J., Zheng X.X., Umetsu D.T., DeKruyff R.H., Strom T.B., Kuchroo V.K. Tim-4 is the ligand for Tim-1, and the Tim-1-Tim-4 interaction regulates $T$ cell expansion. Nat Immunol 2005; 6(5): 455-464, https://doi. org/10.1038/ni1185.

13. Wilker P.R., Sedy J.R., Grigura V., Murphy T.L., Murphy K.M. Evidence for carbohydrate recognition and homotypic and heterotypic binding by the TIM family. Int Immunol 2007; 19(6): 763-773, https://doi.org/10.1093/intimm/ dxm044.

14. Ichimura T., Asseldonk E.J., Humphreys B.D., Gunaratnam L., Duffield J.S., Bonventre J.V. Kidney injury molecule-1 is a phosphatidylserine receptor that confers a phagocytic phenotype on epithelial cells. J Clin Investig 2008; 118(5): 1657-1668, https://doi.org/10.1172/jci34487.

15. Angiari S., Donnarumma T., Rossi B., Dusi S., Pietronigro E., Zenaro E., Della Bianca V., Toffali L., Piacentino G., Budui S., Rennert P., Xiao S., Laudanna C., Casasnovas J.M., Kuchroo V.K., Constantin G. TIM-1 glycoprotein binds the adhesion receptor P-selectin and mediates $\mathrm{T}$ cell trafficking during inflammation and autoimmunity. Immunity 2014; 40(4): 542-553, https://doi. org/10.1016/j.immuni.2014.03.004.

16. Corral-Jara K.F., Trujillo-Ochoa J.L., Realpe M., Panduro A., Gómez-Leyva J.F., Rosenstein Y., JoseAbrego A., Roman S., Fierro N.A. Conjugated bilirubin differentially regulates $\mathrm{CD}^{+} \mathrm{T}$ effector cells and $\mathrm{T}$ regulatory cell function through outside-in and inside-out mechanisms: the effects of HAV cell surface receptor and intracellular signaling. Mediators Inflamm 2016; 2016: 1759027, https://doi. org/10.1155/2016/1759027

17. Kane L.P. T cell Ig and mucin domain proteins and immunity. J Immunol 2010; 184(6): 2743-2749, https://doi. org/10.4049/jimmunol.0902937.

18. Nakajima T., Wooding S., Satta Y., Jinnai N., Goto S., Hayasaka I., Saitou N., Guan-Jun J., Tokunaga K., Jorde L.B., Emi M., Inoue I. Evidence for natural selection in the HAVCR1 gene: high degree of amino-acid variability in the mucin domain of human HAVCR1 protein. Genes Immun 2005; 6(5): 398-406, https://doi.org/10.1038/sj.gene.6364215.

19. Feigelstock D., Thompson P., Mattoo P., Zhang Y., Kaplan G.G. The human homolog of HAVcr-1 codes for a hepatitis A virus cellular receptor. J Virol 1998; 72(8): 66216628, https://doi.org/10.1128/jvi.72.8.6621-6628.1998.

20. Evans J.P., Liu S.L. Multifaceted roles of TIM-family proteins in virus-host interactions. Trends Microbiol 2020; 28(3): 224-235, https://doi.org/10.1016/j.tim.2019.10.004.

21. Amara A., Mercer J. Viral apoptotic mimicry. Nat Rev Microbiol 2015; 13(8): 461-469, https://doi.org/10.1038/ nrmicro3469.

22. Biasin M., Sironi M., Saulle I., Pontremoli C., Garziano M., Cagliani R., Trabattoni D., Lo Caputo S., Vichi F., Mazzotta F., Forni D., Riva S., Aguilar-Jimenez W., Cedeño S., Sanchez J., Brander C., Zapata W., Rugeles M.T., Clerici M. A 6-amino acid insertion/deletion polymorphism in the mucin domain of TIM-1 confers protections against HIV-1 infection. Microbes Infect 2017; 19(1): 69-74, https://doi.org/10.1016/j. micinf.2016.09.005.

23. Kuroda M., Fujikura D., Noyori O., Kajihara M., Maruyama J., Miyamoto H., Yoshida R., Takada A. 
A polymorphism of the TIM-1 IgV domain: implications for the susceptibility to filovirus infection. Biochem Biophys Res Commun 2014; 455(3-4): 223-228, https://doi.org/10.1016/j. bbrc.2014.10.144.

24. Kim H.Y., Eyheramonho M.B., Pichavant M., Gonzalez Cambaceres C., Matangkasombut P., Cervio G., Kuperman S., Moreiro R., Konduru K., Manangeeswaran M., Freeman G.J., Kaplan G.G., DeKruyff R.H., Umetsu D.T., Rosenzweig S.D. A polymorphism in TIM1 is associated with susceptibility to severe hepatitis A virus infection in humans. J Clin Invest 2011; 121(3): 1111-1118, https://doi.org/10.1172/jci44182.

25. Wojcik G., Latanich R., Mosbruger T., Astemborski J., Kirk G.D., Mehta S.H., Goedert J.J., Kim A.Y., Seaberg E.C., Busch M., Thomas D.L., Duggal P., Thio C.L. Variants in HAVCR1 gene region contribute to hepatitis $C$ persistence in African Americans. J Infect Dis 2014; 209(3): 355-359, https:// doi.org/10.1093/infdis/jit444.

26. Younan P., lampietro M., Nishida A., Ramanathan P., Santos R.I., Dutta M., Lubaki N.M., Koup R.A., Katze M.G., Bukreyev A. Ebola virus binding to Tim-1 on T lymphocytes induces a cytokine storm. mBio 2017; 8(5): e00845-17, https:// doi.org/10.1128/mbio.00845-17.

27. Li M., Ablan S.D., Miao C., Zheng Y.M., Fuller M.S., Rennert P.D., Maury W., Johnson M.C., Freed E.O., Liu S.L. TIM-family proteins inhibit HIV-1 release. Proc Natl Acad Sci U S A 2014; 111(35): E3699-E3707, https://doi.org/10.1073/ pnas. 1404851111.

28. Xiao S., Najafian N., Reddy J., Albin M., Zhu C., Jensen E., Imitola J., Korn T., Anderson A.C., Zhang Z., Gutierrez C., Moll T., Sobel R.A., Umetsu D.T., Yagita H., Akiba H., Strom T., Sayegh M.H., DeKruyff R.H., Khoury S.J., Kuchroo V.K. Differential engagement of Tim-1 during activation can positively or negatively costimulate $T$ cell expansion and effector function. J Exp Med 2007; 204(7): 1691-1702, https://doi.org/10.1084/jem.20062498.

29. Freeman G.J., Casasnovas J.M., Umetsu D.T., DeKruyff R.H. TIM genes: a family of cell surface phosphatidylserine receptors that regulate innate and adaptive immunity. Immunol Rev 2010; 235(1): 172-189, https://doi. org/10.1111/j.0105-2896.2010.00903.x.

30. Rodriguez-Manzanet R., DeKruyff R., Kuchroo V.K., Umetsu D.T. The costimulatory role of TIM molecules. Immunol Rev 2009; 229(1): 259-270, https://doi.org/10.1111/j.1600065x.2009.00772.x.

31. Lee H.H., Meyer E.H., Goya S., Pichavant M., Kim H.Y., Bu X., Umetsu S.E., Jones J.C., Savage P.B., Iwakura Y., Casasnovas J.M., Kaplan G., Freeman G.J., DeKruyff R.H., Umetsu D.T. Apoptotic cells activate NKT cells through $T$ cell Ig-like mucin-like-1 resulting in airway hyperreactivity. J Immunol 2010; 185(9): 5225-5235, https://doi.org/10.4049/ jimmunol.1001116.

32. Rennert P.D. Novel roles for TIM-1 in immunity and infection. Immunol Lett 2011; 141(1): 28-35, https://doi. org/10.1016/j.imlet.2011.08.003.

33. Binné L.L., Scott M.L., Rennert P.D. Human TIM-1 associates with the TCR complex and up-regulates T cell activation signals. J Immunol 2007; 178(7): 4342-4350, https:// doi.org/10.4049/jimmunol.178.7.4342.

34. Echbarthi M., Zonca M., Mellwig R., Schwab Y., Kaplan G., DeKruyff R.H., Roda-Navarro P., Casasnovas J.M. Distinct trafficking of cell surface and endosomal TIM-1 to the immune synapse. Traffic 2015; 16(11): 1193-1207, https://doi. org/10.1111/tra.12329.
35. de Souza A.J., Oak J.S., Jordanhazy R., DeKruyff R.H., Fruman D.A., Kane L.P. T cell $\mathrm{lg}$ and mucin domain-1mediated $T$ cell activation requires recruitment and activation of phosphoinositide 3-kinase. J Immunol 2008; 180(10): 65186526, https://doi.org/10.4049/jimmunol.180.10.6518.

36. Angiari S., Constantin G. Regulation of $T$ cell trafficking by the $T$ cell immunoglobulin and mucin domain 1 glycoprotein. Trends Mol Med 2014; 20(12): 675-684, https:// doi.org/10.1016/j.molmed.2014.10.003.

37. Xu J., Jiang P., Liu J. Pooled-analysis of the association between TIM-1 5383_5397 insertion/deletion polymorphism and asthma susceptibility. Mol Biol Rep 2014; 41(12): 78257831, https://doi.org/10.1007/s11033-014-3676-6.

38. Mete F., Ozkaya E., Aras S., Koksal V., Etlik O., Baris I. Association between gene polymorphisms in TIM1, TSLP, IL18R1 and childhood asthma in Turkish population. Int J Clin Exp Med 2014; 7(4): 1071-1077.

39. Shirzade H., Meshkat R., Ganjalikhani-Hakemi M., Mosayebian A., Ghasemi R., Deress F., Parchami Barjui S., Sadri M., Salehi R. Association analysis of $-416 \quad G>C$ polymorphism of T-cell immunoglobulin and mucin domain-1 gene with asthma in Iran. Int J Immunogenet 2015; 42(4): 265269, https://doi.org/10.1111/iji.12209.

40. Xie X., Shi X., Chen P., Rao L. Associations of TIM-1 genetic polymorphisms with asthma: a meta-analysis. Lung 2017; 195(3): 353-360, https://doi.org/10.1007/s00408-0170006-5.

41. Yu Y., Zhu C., Zhou S., Chi S. Association between C1q, TRAIL, and Tim-1 gene polymorphisms and systemic lupus erythematosus. Genet Test Mol Biomarkers 2018; 22(9): 546-553, https://doi.org/10.1089/gtmb.2018.0056.

42. Liu Y., Xu H.B. Genetic polymorphisms of rs 9313422 G>C and rs41297579 G>A at the promoter of TIM-1 gene contribute to the risk of community-acquired pneumonia in children. J Clin Lab Anal 2020; 34(3): e23095, https://doi. org/10.1002/jcla.23095.

43. Degauque N., Mariat C., Kenny J., Zhang D., Gao W., Vu M.D., Alexopoulos S., Oukka M., Umetsu D.T., DeKruyff R.H., Kuchroo V., Zheng X.X., Strom T.B. Immunostimulatory Tim-1-specific antibody deprograms Tregs and prevents transplant tolerance in mice. J Clin Invest 2008; 118(2): 735-741, https://doi.org/10.1172/jci32562.

44. Guo H., Shen Y., Kong Y.H., Li S., Jiang R., Liu C., Fang C., Hu J. The expression of Tim-1 and Tim-4 molecules in regulatory T cells in type 1 diabetes. Endocrine 2020; 68(1): 64-70, https://doi.org/10.1007/s12020-019-02173-8.

45. Ding Q., Yeung M., Camirand G., Zeng Q., Akiba H., Yagita H., Chalasani G., Sayegh M.H., Najafian N., Rothstein D.M. Regulatory B cells are identified by expression of TIM-1 and can be induced through TIM-1 ligation to promote tolerance in mice. J Clin Invest 2011; 121: 3645-3656, https:// doi.org/10.1172/jci46274.

46. Mauri C., Menon M. Human regulatory B cells in health and disease: therapeutic potential. J Clin Invest 2017; 127(3): 772-779, https://doi.org/10.1172/jci85113.

47. Zhu G., Liu Y., Zhang W., Huang Y., Li K. CD $27^{+}$TIM-1 ${ }^{+}$ memory B cells promoted the development of Foxp3 $3^{+}$Tregs and were associated with better survival in acute respiratory distress syndrome. Immunol Res 2018; 66(2): 281-287, https:// doi.org/10.1007/s12026-017-8983-2.

48. Aravena O., Ferrier A., Menon M., Mauri C., Aguillón J.C., Soto L., Catalán D. TIM-1 defines a human regulatory $B$ cell population that is altered in frequency and 
function in systemic sclerosis patients. Arthritis Res Ther 2017; 19(1): 8, https://doi.org/10.1186/s13075-016-1213-9.

49. Zhang Y., Zhang X., Xia Y., Jia X., Li H., Zhang Y., Shao Z., Xin N., Guo M., Chen J., Zheng S., Wang Y., Fu L., Xiao C., Geng D., Liu Y., Cui G., Dong R., Huang X., Yu T. CD $19^{+}$Tim $-1^{+} B$ cells are decreased and negatively correlated with disease severity in Myasthenia Gravis patients. Immunol Res 2016; 64(5-6): 1216-1224, https://doi.org/10.1007/ s12026-016-8872-0.

50. Xue H., Lin F., Tan H., Zhu Z.Q., Zhang Z.Y., Zhao L. Overrepresentation of IL-10-expressing $B$ cells suppresses cytotoxic $\mathrm{CD}^{+} \mathrm{T}$ cell activity in HBV-induced hepatocellular carcinoma. PLoS One 2016; 11(5): e0154815, https://doi. org/10.1371/journal.pone.0154815.

51. Ye L., Zhang Q., Cheng Y., Chen X., Wang G., Shi M., Zhang T., Cao Y., Pan H., Zhang L., Wang G., Deng Y., Yang Y., Chen G. Tumor-derived exosomal HMGB1 fosters hepatocellular carcinoma immune evasion by promoting TIM-1 ${ }^{+}$ regulatory B cell expansion. J Immunother Cancer 2018; 6(1): 145, https://doi.org/10.1186/s40425-018-0451-6.

52. Baghdadi M., Takeuchi S., Wada H., Seino K. Blocking monoclonal antibodies of TIM proteins as orchestrators of antitumor immune response. MAbs 2014; 6(5): 1124-1132, https:// doi.org/10.4161/mabs.32107.

53. Iliopoulou B.P., Hsu K., Pérez-Cruz M., Tang S.W., Pang W.W., Erkers T., Kambham N., Freeman G.J., Dekruyff R.H., Meyer E.H. Blockade of TIM-1 on the donor graft ameliorates graft-versus-host disease following hematopoietic cell transplantation. Blood Adv 2019; 3(21): 3419-3431, https:// doi.org/10.1182/bloodadvances.2019000286.

54. Guo Y.Y., Yin C.J., Zhao M., Guo L.T., Su R.F., Fu X.X., Dong W.L., Tan X.B. Effect of RMT1-10 on the immunological characteristics of dendritic cells cultured in vitro and corneal transplantation in vivo. Eur Rev Med Pharmacol Sci 2019; 23(21): 9150-9162, https://doi.org/10.26355/ eurrev_201911_19405.

55. Smirnov A.V., Kayukov I.G., Dobronravov V.A., Rumyantsev A.S. Acute kidney injury: conceptual problems. Nefrologia 2014; 18(2): 8-24.

56. Makris K., Spanou L. Acute kidney injury: definition, pathophysiology and clinical phenotypes. Clin Biochem Rev 2016; 37(2): 85-98.

57. Andrianova N.V., Buyan M.I., Zorova L.D., Pevzner I.B., Popkov V.A., Babenko V.A., Silachev D.N., Plotnikov E.Y., Zorov D.B. Kidney cells regeneration: dedifferentiation of tubular epithelium, resident stem cells and possible niches for renal progenitors. Int J Mol Sci 2019; 20(24): E6326, https:// doi.org/10.3390/ijms20246326.

58. Ichimura T., Hung C.C., Yang S.A., Stevens J.L., Bonventre J.V. Kidney injury molecule-1: a tissue and urinary biomarker for nephrotoxicant-induced renal injury. $A m \mathrm{~J}$ Physiol Renal Physiol 2004; 286(3): F552-F563, https://doi. org/10.1152/ajprenal.00285.2002.

59. Zhang P.L., Rothblum L.I., Han W.K., Blasick T.M., Potdar S., Bonventre J.V. Kidney injury molecule-1 expression in transplant biopsies is a sensitive measure of cell injury. Kidney Int 2008; 73(5): 608-614, https://doi.org/10.1038/sj.ki.5002697.

60. Brooks C.R., Yeung M.Y., Brooks Y.S., Chen H., Ichimura T., Henderson J.M., Bonventre J.V. KIM-1-/TIM-1mediated phagocytosis links ATG5-/ULK1-dependent clearance of apoptotic cells to antigen presentation. EMBO J 2015; 34(19): 2441-2464, https://doi.org/10.15252/embj.201489838.

61. Zhao X., Jiang C., Olufade R., Liu D., Emmett N. Kidney injury molecule- 1 enhances endocytosis of albumin in renal proximal tubular cells. J Cell Physiol 2016; 231(4): 896-907, https://doi.org/10.1002/jcp.25181.

62. Yang L., Brooks C.R., Xiao S., Sabbisetti V., Yeung M.Y., Hsiao L.L., Ichimura T., Kuchroo V., Bonventre J.V. KIM-1-mediated phagocytosis reduces acute injury to the kidney. J Clin Invest 2015; 125(4): 1620-1636, https://doi. org/10.1172/jci75417.

63. Ismail O.Z., Zhang X., Wei J., Haig A., Denker B.M., Suri R.S., Sener A., Gunaratnam L. Kidney injury molecule-1 protects against $\mathrm{G} \alpha 12$ activation and tissue damage in renal ischemia-reperfusion injury. Am J Pathol 2015; 185(5): 12071215, https://doi.org/10.1016/j.ajpath.2015.02.003.

64. Balasubramanian S., Jansen M., Valerius M.T., Humphreys B.D., Strom T.B. Orphan nuclear receptor Nur77 promotes acute kidney injury and renal epithelial apoptosis. J Am Soc Nephrol 2012; 23(4): 674-686, https://doi. org/10.1681/asn.2011070646.

65. Zhang Z., Cai C.X. Kidney injury molecule-1 (KIM-1) mediates renal epithelial cell repair via ERK MAPK signaling pathway. Mol Cell Biochem 2016; 416(1-2): 109-116, https:// doi.org/10.1007/s11010-016-2700-7.

66. Lim A.I., Tang S.C., Lai K.N., Leung J.C. Kidney injury molecule-1: more than just an injury marker of tubular epithelial cells? J Cell Physiol 2013; 228(5): 917-924, https://doi. org/10.1002/jcp.24267.

67. Zhang Z., Humphreys B.D., Bonventre J.V. Shedding of the urinary biomarker kidney injury molecule-1 (KIM-1) is regulated by MAP kinase and juxtamembrane region. J Am Soc Nephrol 2007; 18(10): 2704-2714, https://doi.org/10.1681/ asn.2007030325.

68. Myers B.D., Chui F., Hilberman M., Michaels A.S. Transtubular leakage of glomerular filtrate in human acute renal failure. Am J Physiol 1979; 237(4): F319-325, https://doi. org/10.1152/ajprenal.1979.237.4.F319.

69. Sabbisetti V.S., Waikar S.S., Antoine D.J., Smiles A., Wang C., Ravisankar A., Ito K., Sharma S., Ramadesikan S. Lee M., Briskin R., De Jager P.L., Ngo T.T., Radlinski M., Dear J.W., Park K.B., Betensky R., Krolewski A.S., Bonventre J.V. Blood kidney injury molecule-1 is a biomarker of acute and chronic kidney injury and predicts progression to ESRD in type I diabetes. J Am Soc Nephrol 2014; 25(10): 2177-2186, https://doi.org/10.1681/asn.2013070758.

70. Bonventre J.V. Kidney injury molecule-1 (KIM-1): a urinary biomarker and much more. Nephrol Dial Transplant 2009; 24(11): 3265-3268, https://doi.org/10.1093/ndt/gfp010.

71. Dieterle F., Sistare F., Goodsaid F., Papaluca M., Ozer J.S., Webb C.P., Baer W., Senagore A., Schipper M.J., Vonderscher J., Sultana S., Gerhold D.L., Phillips J.A., Maurer G., Carl K., Laurie D., Harpur E., Sonee M., Ennulat D. Holder D., Andrews-Cleavenger D., Gu Y.Z., Thompson K.L., Goering P.L., Vidal J.M., Abadie E., Maciulaitis R., JacobsonKram D., Defelice A.F., Hausner E.A., Blank M., Thompson A., Harlow P., Throckmorton D., Xiao S., Xu N., Taylor W., Vamvakas S., Flamion B., Lima B.S., Kasper P., Pasanen M., Prasad K., Troth S., Bounous D., Robinson-Gravatt D., Betton G., Davis M.A., Akunda J., McDuffie J.E., Suter L., Obert L., Guffroy M., Pinches M., Jayadev S., Blomme E.A., Beushausen S.A., Barlow V.G., Collins N., Waring J., Honor D., Snook S., Lee J., Rossi P., Walker E., Mattes W. Renal biomarker qualification submission: a dialog between the FDAEMEA and predictive safety testing consortium. Nat Biotechnol 2010; 28(5): 455-462, https://doi.org/10.1038/nbt.1625. 
72. Chen R., Sanyal S., Thompson A., Ix J.H., Haskins K., Muldowney L., Amur S. Evaluating the use of KIM-1 in drug development and research following FDA qualification. Clin Pharmacol Ther 2018; 104(6): 1175-1181, https://doi. org/10.1002/cpt.1093.

73. Shao X., Tian L., Xu W., Zhang Z., Wang C., Qi C., $\mathrm{Ni} Z$., Mou S. Diagnostic value of urinary kidney injury molecule 1 for acute kidney injury: a meta-analysis. PLoS One 2014; 9(1): e84131, https://doi.org/10.1371/journal.pone.0084131.

74. Vaidya V.S., Ozer J.S., Dieterle F., Collings F.B., Ramirez V., Troth S., Muniappa N., Thudium D., Gerhold D., Holder D.J., Bobadilla N.A., Marrer E., Perentes E., Cordier A., Vonderscher J., Maurer G., Goering P.L., Sistare F.D., Bonventre J.V. Kidney injury molecule-1 outperforms traditional biomarkers of kidney injury in preclinical biomarker qualification studies. Nat Biotechnol 2010; 28(5): 478-485, https://doi. org/10.1038/nbt.1623.

75. Zheng J.S., Jing-Nie, Zhu T.T., Ruan H.R., Xue-Wei, Rui-Wu. Screening of early diagnostic markers of gentamicininduced acute kidney injury in canines. J Vet Res 2019; 63(3): 405-411, https://doi.org/10.2478/jvetres-2019-0048.

76. Bland S.K., Schmiedt C.W., Clark M.E., DeLay J., Bienzle D. Expression of kidney injury molecule-1 in healthy and diseased feline kidney tissue. Vet Pathol 2017; 54(3): 490-510, https://doi.org/10.1177/0300985817690213.

77. Wen X., Cui L., Morrisroe S., Maberry D. Jr., Emlet D., Watkins S., Hukriede N.A., Kellum J.A. A zebrafish model of infection-associated acute kidney injury. Am J Physiol Renal Physiol 2018; 315(2): F291-F299, https://doi.org/10.1152/ ajprenal.00328.2017.

78. Santos M.L.C., de Brito B.B., da Silva F.A.F., Botelho A.C.D.S., de Melo F.F. Nephrotoxicity in cancer treatment: an overview. World J Clin Oncol 2020; 11(4): 190204, https://doi.org/10.5306/wjco.v11.i4.190.

79. Sahni V., Choudhury D., Ahmed Z. Chemotherapyassociated renal dysfunction. Nat Rev Nephrol 2009; 5(8): 450-462, https://doi.org/10.1038/nrneph.2009.97.

80. George B., Joy M.S., Aleksunes L.M. Urinary protein biomarkers of kidney injury in patients receiving cisplatin chemotherapy. Exp Biol Med (Maywood) 2018; 243(3): 272 282, https://doi.org/10.1177/1535370217745302.

81. Griffin B.R., Faubel S., Edelstein C.L. Biomarkers of drug-induced kidney toxicity. Ther Drug Monit 2019; 41(2): 213-226, https://doi.org/10.1097/ftd.0000000000000589.

82. Chazot R., Botelho-Nevers E., Frésard A., Maillard N., Mariat C., Lucht F., Gagneux-Brunon A. Diagnostic challenges of kidney diseases in HIV-infected patients. Expert Rev Anti Infect Ther 2017; 15(10): 903-915, https://doi.org/10.1080/ 14787210.2017.1379395.

83. Pang H.M., Qin X.L., Liu T.T., Wei W.X., Cheng D.H., Lu H., Guo Q., Jing L. Urinary kidney injury molecule-1 and neutrophil gelatinase-associated lipocalin as early biomarkers for predicting vancomycin-associated acute kidney injury: a prospective study. Eur Rev Med Pharmacol Sci 2017; 21(18): 4203-4213.

84. Li Z., Shen C., Wang Y., Wang W., Zhao Q., Liu Z., Wang Y., Zhao C. Circulating kidney injury molecule-1 is a novel diagnostic biomarker for renal dysfunction during long-term adefovir therapy in chronic hepatitis B. Medicine (Baltimore) 2016; 95(44): e5264, https://doi.org/10.1097/ md.0000000000005264.

85. Antoine D.J., Sabbisetti V.S., Francis B., Jorgensen A.L., Craig D.G., Simpson K.J., Bonventre J.V.,
Park B.K., Dear J.W. Circulating kidney injury molecule 1 predicts prognosis and poor outcome in patients with acetaminophen-induced liver injury. Hepatology 2015; 62(2): 591-599, https://doi.org/10.1002/hep.27857.

86. Torregrosa I., Montoliu C., Urios A., Andrés-Costa M.J., Giménez-Garzó C., Juan I., Puchades M.J., Blasco M.L., Carratalá A., Sanjuán R., Miguel A. Urinary KIM-1, NGAL and $\mathrm{L}-\mathrm{FABP}$ for the diagnosis of $\mathrm{AKI}$ in patients with acute coronary syndrome or heart failure undergoing coronary angiography. Heart Vessels 2015; 30(6): 703-711, https://doi.org/10.1007/ s00380-014-0538-z.

87. Wybraniec M.T., Chudek J., Bożentowicz-Wikarek M., Mizia-Stec K. Prediction of contrast-induced acute kidney injury by early post-procedural analysis of urinary biomarkers and intra-renal Doppler flow indices in patients undergoing coronary angiography. J Interv Cardiol 2017; 30(5): 465-472, https://doi.org/10.1111/joic.12404.

88. Ibrahim N.E., McCarthy C.P., Shrestha S., Lyass A., Li Y., Gaggin H.K., Simon M.L., Massaro J.M., D'Agostino R.B. Sr., Garasic J.M., van Kimmenade R.R., Januzzi J.L. Jr. Blood kidney injury molecule-1 predicts short and longer term kidney outcomes in patients undergoing diagnostic coronary and/or peripheral angiography - results from the Catheter Sampled Blood Archive in Cardiovascular Diseases (CASABLANCA) study. Am Heart J 2019; 209: 3646, https://doi.org/10.1016/j.ahj.2018.12.001.

89. van Timmeren M.M., Vaidya V.S., van Ree R.M., Oterdoom L.H., de Vries A.P., Gans R.O., van Goor H., Stegeman C.A., Bonventre J.V., Bakker S.J. High urinary excretion of kidney injury molecule-1 is an independent predictor of graft loss in renal transplant recipients. Transplantation 2007; 84(12): 1625-1630, https://doi. org/10.1097/01.tp.0000295982.78039.ef.

90. Nogare A.L., Veronese F.V., Carpio V.N., Montenegro R.M., Pedroso J.A., Pegas K.L., Gonçalves L.F., Manfro R.C. Kidney injury molecule-1 expression in human kidney transplants with interstitial fibrosis and tubular atrophy. BMC Nephrol 2015; 16: 19, https://doi.org/10.1186/s12882015-0011-y.

91. Bank J.R., van der Pol P., Vreeken D., MongeChaubo C., Bajema I.M., Schlagwein N., van Gijlswijk D.J., van der Kooij S.W., Reinders M.E.J., de Fijter J.W., van Kooten C. Kidney injury molecule-1 staining in renal allograft biopsies 10 days after transplantation is inversely correlated with functioning proximal tubular epithelial cells. Nephrol Dial Transplant 2017; 32(12): 2132-2141, https://doi. org/10.1093/ndt/gfx286.

92. Shahbaz S.K., Pourrezagholi F., Barabadi M., Foroughi F., Hosseinzadeh M., Ahmadpoor P., Nafar M., Yekaninejad M.S., Amirzargar A. High expression of TIM-3 and KIM-1 in blood and urine of renal allograft rejection patients. Transpl Immunol 2017; 43-44: 11-20, https://doi.org/10.1016/j. trim.2017.07.002.

93. Keshavarz Shahbaz S., Pourrezagholi F., Nafar M., Ahmadpoor P., Barabadi M., Foroughi F., Hosseinzadeh M., Yekaninejad M.S., Amirzargar A. Dynamic variation of kidney injury molecule-1 mRNA and protein expression in blood and urine of renal transplant recipients: a cohort study. Clin Exp Nephrol 2019; 23(10): 235-1249, https://doi.org/10.1007/ s10157-019-01765-y.

94. Tu Y., Wang H., Sun R., Ni Y., Ma L., Xv F., Hu X., Jiang L., Wu A., Chen X., Chen M., Liu J., Han F. Urinary netrin-1 and KIM-1 as early biomarkers for septic acute kidney 
injury. Ren Fail 2014; 36(10): 1559-1563, https://doi.org/10. 3109/0886022x.2014.949764.

95. Krzemień G., Turczyn A., Pańczyk-Tomaszewska M., Kotuła I., Demkow U., Szmigielska A. Prognostic value of serum and urine kidney injury molecule- 1 in infants with urinary tract infection. Cent Eur J Immunol 2019; 44(3): 262-268, https://doi.org/10.5114/ceji.2019.89600.

96. Kostic D., Beozzo G.P.N.S., do Couto S.B., Kato A.H.T., Lima L., Palmeira P., Krebs V.L.J., Bunduki V., Francisco R.P.V., Zugaib M., Dénes F.T., de Carvalho W.B., Koch V.H.K. The role of renal biomarkers to predict the need of surgery in congenital urinary tract obstruction in infants J Pediatr Urol 2019; 15(3): 242.e1-242.e9, https://doi. org/10.1016/j.jpurol.2019.03.009.

97. Romagnani P., Remuzzi G., Glassock R., Levin A., Jager K.J., Tonelli M., Massy Z., Wanner C., Anders H.J. Chronic kidney disease. Nat Rev Dis Primers 2017; 3: 17088, https://doi.org/10.1038/nrdp.2017.88.

98. Kuzmin O.B. Chronic kidney disease: mechanisms of hypoxic glomerulosclerosis and tubulointerstitial fibrosis development and progression. Nefrologia 2015; 19(4): 6-16.

99. Cruz-Solbes A.S., Youker K. Epithelial to mesenchymal transition (EMT) and endothelial to mesenchymal transition (EndMT): role and implications in kidney fibrosis. Results Probl Cell Differ 2017; 60: 345-372, https://doi.org/10.1007/978-3319-51436-9_13.

100. Lin Q., Chen Y., Lv J., Zhang H., Tang J., Gunaratnam L., Li X., Yang L. Kidney injury molecule-1 expression in IgA nephropathy and its correlation with hypoxia and tubulointerstitial inflammation. Am J Physiol Renal Physiol 2014; 306(8): F885-F895, https://doi.org/10.1152/ ajprenal.00331.2013.

101. Tian L., Shao X., Xie Y., Wang Q., Che X., Zhang M., Xu W., Xu Y., Mou S., Ni Z. Kidney injury molecule-1 is elevated in nephropathy and mediates macrophage activation via the Mapk signalling pathway. Cell Physiol Biochem 2017; 41(2): 769-783, https://doi.org/10.1159/000458737.

102. Yamanishi Y., Kitaura J., Izawa K., Kaitani A., Komeno Y., Nakamura M., Yamazaki S., Enomoto Y., Oki T., Akiba H., Abe T., Komori T., Morikawa Y., Kiyonari H., Takai T., Okumura K., Kitamura T. TIM1 is an endogenous ligand for LMIR5/CD300b: LMIR5 deficiency ameliorates mouse kidney ischemia/reperfusion injury. J Exp Med 2010; 207(7): 15011511, https://doi.org/10.1084/jem.20090581.

103. Humphreys B.D., Xu F., Sabbisetti V., Grgic I., Movahedi Naini S., Wang N., Chen G., Xiao S., Patel D., Henderson J.M., Ichimura T., Mou S., Soeung S., McMahon A.P., Kuchroo V.K., Bonventre J.V. Chronic epithelial kidney injury molecule-1 expression causes murine kidney fibrosis. J Clin Invest 2013; 123(9): 4023-4035, https://doi.org/10.1172/jci45361.

104. Zhou L.T., Lv L.L., Pan M.M., Cao Y.H., Liu H., Feng Y., Ni H.F., Liu B.C. Are urinary tubular injury markers useful in chronic kidney disease? A systematic review and meta analysis. PLoS One 2016; 11(12): e0167334, https://doi. org/10.1371/journal.pone.0167334.

105. Ntrinias T., Papasotiriou M., Balta L., Kalavrizioti D., Vamvakas S., Papachristou E., Goumenos D.S. Biomarkers in progressive chronic kidney disease. Still a long way to go. Pril (Makedon Akad Nauk Umet Odd Med Nauki) 2019; 40(3): 27-39, https://doi.org/10.2478/prilozi-2020-0002.

106. Seibert F.S., Sitz M., Passfall J., Haesner M., Laschinski P., Buhl M., Bauer F., Babel N., Pagonas N., Westhoff T.H. Prognostic value of urinary calprotectin, NGAL and KIM-1 in chronic kidney disease. Kidney Blood Press Res 2018; 43(4): 1255-1262, https://doi.org/10.1159/000492407.

107. Xu P.C., Zhang J.J., Chen M., Lv J.C., Liu G., Zou W.Z., Zhang H., Zhao M.H. Urinary kidney injury molecule-1 in patients with $\lg A$ nephropathy is closely associated with disease severity. Nephrol Dial Transplant 2011; 26(10): 3229-3236, https://doi.org/10.1093/ndt/gfr023.

108. Ding Y., Nie L.M., Pang Y., Wu W.J., Tan Y., Yu F., Zhao M.H. Composite urinary biomarkers to predict pathological tubulointerstitial lesions in lupus nephritis. Lupus 2018; 27(11): 1778-1789, https://doi.org/10.1177/0961203318788167.

109. Brovko M.Yu., Pulin A.A., Kustova T.Yu., Sholomova V.I., Loshkareva O.A., Taranova M.V., Kozlovskaya L.V. Significance of the determination of urinary excretion of kidney injury molecule-1 (KIM-1) in the assessment of the activity and prognosis of chronic glomerulonephritis. Terapevticeskij arhiv 2016; 88(6): 51-57, https://doi.org/10.17116/terarkh201688651-57.

110. Bulanov N.M., Serova A.G., Kuznetsova E.I., Bulanova M.L., Novikov P.I., Kozlovskaya L.V., Moiseev S.V. Kidney injury molecules (KIM-1, MCP-1) and type IV collagen in the assessment of activity of antineutrophil cytoplasmic antibody-associated glomerulonephritis. Terapevticeskij arhiv 2017; 89(6): 48-55, https://doi.org/10.17116/ terarkh201789648-55.

111. Waikar S.S., Sabbisetti V., Ärnlöv J., Carlsson A.C., Coresh J., Feldman H.I., Foster M.C., Fufaa G.D., HelmerssonKarlqvist J., Hsu C.-Y., Kimmel P.L., Larsson A., Liu Y., Lind L., Liu K.D., Mifflin T.E., Nelson R.G., Risérus U., Vasan R.S., Xie D., Zhang X., Bonventre J.V.; Chronic Kidney Disease Biomarkers Consortium Investigators. Relationship of proximal tubular injury to chronic kidney disease as assessed by urinary kidney injury molecule-1 in five cohort studies. Nephrol Dial Transplant 2016; 31(9): 1460-1470, https://doi.org/10.1093/ ndt/gfw203.

112. Satirapoj B., Pooluea P., Nata N., Supasyndh O.J. Urinary biomarkers of tubular injury to predict renal progression and end stage renal disease in type 2 diabetes mellitus with advanced nephropathy: a prospective cohort study. J Diabetes Complications 2019; 33(9): 675-681, https://doi.org/10.1016/j. jdiacomp.2019.05.013.

113. Gohda T., Kamei N., Koshida T., Kubota M., Tanaka K., Yamashita Y., Adachi E., Ichikawa S., Murakoshi M., Ueda S., Suzuki Y. Circulating kidney injury molecule-1 as a biomarker of renal parameters in diabetic kidney disease. $J$ Diabetes Investig 2020; 11(2): 435-440, https://doi.org/10.1111/ jdi.13139.

114. Nowak N., Skupien J., Niewczas M.A., Yamanouchi M., Major M., Croall S., Smiles A., Warram J.H., Bonventre J.V., Krolewski A.S. Increased plasma kidney injury molecule-1 suggests early progressive renal decline in nonproteinuric patients with type 1 diabetes. Kidney Int 2016; 89(2): 459-467, https://doi.org/10.1038/ki.2015.314.

115. Kuzmin O.B. Chronic kidney disease and cardiovascular system. Nefrologia 2007; 11(1): 28-37.

116. Emmens J.E., Ter Maaten J.M., Matsue Y., Metra M., O'Connor C.M., Ponikowski P., Teerlink J.R., Cotter G., Davison B., Cleland J.G., Givertz M.M., Bloomfield D.M., Dittrich H.C., Todd J., van Veldhuisen D.J., Hillege H.L., Damman K., van der Meer P., Voors A.A. Plasma kidney injury molecule-1 in heart failure: renal mechanisms and clinical outcome. Eur J Heart Fail 2016; 18(6): 641-649, https://doi. org/10.1002/ejhf.426. 
117. Tonkonogi A., Carlsson A.C., Helmersson-Karlqvist J., Larsson A., Ärnlöv J. Associations between urinary kidney injury biomarkers and cardiovascular mortality risk in elderly men with diabetes. Ups J Med Sci 2016; 121(3): 174-178, https://doi.org/ 10.1080/03009734.2016.1192704.

118. Egli P., Aeschbacher S., Bossard M., Eggimann L., Blum S., Meyre P., Bargetzi L., Estis J., Todd J., Risch M., Risch L., Conen D. Relationships of kidney injury molecule-1 with renal function and cardiovascular risk factors in the general population. Clin Chim Acta 2018; 478: 13-17, https:// doi.org/10.1016/j.cca.2017.12.019.

119. Wybraniec M.T., Chudek J., Mizia-Stec K. Association between elevated urinary levels of kidney injury molecule type 1 and adverse cardiovascular events at 12 months in patients with coronary artery disease. Pol Arch Intern Med 2018; 128(5): 301-309, https://doi.org/10.20452/ pamw.4242.

120. Coca S.G., Nadkarni G.N., Garg A.X., Koyner J., Thiessen-Philbrook H., McArthur E., Shlipak M., Parikh C.R.; TRIBE-AKI Consortium. First post-operative urinary kidney injury biomarkers and association with the duration of $A K I$ in the TRIBE-AKI cohort. PLoS One 2016; 11(8): e0161098, https://doi.org/10.1371/journal.pone.0161098.

121. Yuan S.M. Acute kidney injury after cardiac surgery: risk factors and novel biomarkers. Braz J Cardiovasc Surg 2019; 34(3): 352-360, https://doi.org/10.21470/1678-97412018-0212.

122. Neyra J.A., Hu M.C., Minhajuddin A., Nelson G.E., Ahsan S.A., Toto R.D., Jessen M.E., Moe O.W., Fox A.A. Kidney tubular damage and functional biomarkers in acute kidney injury following cardiac surgery. Kidney Int Rep 2019; 4(8): 1131-1142, https://doi.org/10.1016/j.ekir.2019.05.005.

123. Yang C.H., Chang C.H., Chen T.H., Fan P.C., Chang S.W., Chen C.C., Chu P.H., Chen Y.T., Yang H.Y., Yang C.W., Chen Y.C. Combination of urinary biomarkers improves early detection of acute kidney injury in patients with heart failure. Circ J 2016; 80(4): 1017-1023, https://doi. org/10.1253/circj.cj-15-0886.

124. Dubin R.F., Judd S., Scherzer R., Shlipak M., Warnock D.G., Cushman M., Sarnak M., Parikh C., Bennett M., Powe N., Peralta C.A. Urinary tubular injury biomarkers are associated with ESRD and death in the REGARDS Study. Kidney Int Rep 2018; 3(5): 1183-1192, https://doi. org/10.1016/j.ekir.2018.05.013.

125. Foster M.C., Coresh J., Bonventre J.V., Sabbisetti V.S., Waikar S.S., Mifflin T.E., Nelson R.G., Grams M., Feldman H.I., Vasan R.S., Kimmel P.L., Hsu C.Y., Liu K.D.; CKD Biomarkers Consortium. Urinary biomarkers and risk of ESRD in the Atherosclerosis Risk in Communities Study. Clin J Am Soc Nephrol 2015; 10(11): 1956-1963, https://doi. org/10.2215/cjn.02590315.

126. Alekseev B.Y., Anzhiganova Y.V., Lykov A.V., Leonov O.V., Varlamov S.A., Gorbachev A.L., Mager V.O., Demicheva N.N., Mishugin S.V., Zyryanov A.V., Karnaukh P.A., Nikitin R.V. Some specific features of the diagnosis and treatment of kidney cancer in Russia: preliminary results of a multicenter cooperative study. Onkourologia 2012; 8(3): 24-30.

127. Jonasch E., Gao J., Rathmell W.K. Renal cell carcinoma. BMJ 2014; 349: g4797, https://doi.org/10.1136/bmj. g4797.

128. Han W.K., Alinani A., Wu C.L., Michaelson D., Loda M., McGovern F.J., Thadhani R., Bonventre J.V. Human kidney injury molecule-1 a tissue and urinary tumor marker of renal cell carcinoma. J Am Soc Nephrol 2005; 16(4): 11261134, https://doi.org/10.1681/asn.2004070530.

129. Lin F., Zhang P.L., Yang X.J., Shi J., Blasick T., Han W.K., Wang H.L., Shen S.S., Teh B.T., Bonventre J.V. Human kidney injury molecule-1 (hKIM-1): a useful immunohistochemical marker for diagnosing renal cell carcinoma and ovarian clear cell carcinoma. Am J Surg Pathol 2007; 31(3): 371-381, https://doi.org/10.1097/01. pas.0000213353.95508.67.

130. Cuadros T., Trilla E., Vilà M.R., de Torres I., Vilardell J., Ben Messaoud N., Salcedo M., Sarró E., López-Hellin J., Blanco A., Mir C., Ramón y Cajal S., Itarte E., Morote J., Meseguer A. Hepatitis A virus cellular receptor $1 /$ kidney injury molecule- 1 is a susceptibility gene for clear cell renal cell carcinoma and hepatitis A virus cellular receptor/kidney injury molecule-1 ectodomain shedding a predictive biomarker of tumour progression. Eur J Cancer 2013; 49(8): 2034-2047, https://doi.org/10.1016/j.ejca.2012.12.020

131. Zhang P.L., Mashni J.W., Sabbisetti V.S., Schworer C.M., Wilson G.D., Wolforth S.C., Kernen K.M., Seifman B.D., Amin M.B., Geddes T.J., Lin F., Bonventre J.V., Hafron J.M. Urine kidney injury molecule-1: a potential noninvasive biomarker for patients with renal cell carcinoma. Int Urol Nephrol 2014; 46(2): 379-388, https://doi.org/10.1007/ s11255-013-0522-z.

132. Ersavaç S., Diniz G., Yildirim H.T., Koca Y., Kahraman D.S., Ayaz D., Demiraĝ B. Expression of neutrophil gelatinase-associated lipocalin and kidney injury molecule-1 in Wilms tumor. Turk Patoloji Derg 2016; 32(3): 158-163, https:// doi.org/10.5146/tjpath.2015.01360.

133. Martin T.A., Harrison G.M., Mason M.D., Jiang W.G. HAVcR-1 reduces the integrity of human endothelial tight junctions. Anticancer Res 2011; 31(2): 467-473, https://doi. org/10.1158/0008-5472.sabcs-09-2158.

134. Telford E.J., Jiang W.G., Martin T.A. HAVcR-1 involvement in cancer progression. Histol Histopathol 2017; 32(2): 121-128, https://doi.org/10.14670/hh-11-817.

135. Fu Q., Chang Y., An H., Fu H., Zhu Y., Xu L., Zhang W., $\mathrm{Xu}$ J. Prognostic value of interleukin-6 and interleukin-6 receptor in organ-confined clear-cell renal cell carcinoma: a 5-year conditional cancer-specific survival analysis. Br J Cancer 2015; 113(11): 1581-1589, https://doi. org/10.1038/bjc.2015.379.

136. Cuadros T., Trilla E., Sarró E., Vilá M.R., Vilardell J., de Torres I., Salcedo M., López-Hellin J., Sánchez A., Ramón y Cajal S., Itarte E., Morote J., Meseguer A. HAVCR/ KIM-1 activates the IL-6/STAT-3 pathway in clear cell renal cell carcinoma and determines tumor progression and patient outcome. Cancer Res 2014; 74(5): 1416-1428, https://doi. org/10.1158/0008-5472.can-13-1671.

137. de Vivar Chevez A.R., Finke J., Bukowski R. The role of inflammation in kidney cancer. Adv Exp Med Biol 2014; 816: 197-234, https://doi.org/10.1007/978-3-0348-0837-8_9.

138. Morrissey J.J., London A.N., Lambert M.C., Kharasch E.D. Sensitivity and specificity of urinary neutrophil gelatinase-associated lipocalin and kidney injury molecule-1 for the diagnosis of renal cell carcinoma. Am J Nephrol 2011; 34(5): 391-398, https://doi.org/10.1159/000330851.

139. Kit O.I., Frantsiyants E.M., Dimitriadi S.N., Kaplieva I.V., Trepitaki L.K., Cheryarina N.D., Pogorelova Yu.A. Role of markers for acute kidney injury in surgical management of patients with renal cancer. Onkourologia 2015; 11(3): 34-39, https://doi.org/10.17650/1726-9776-2015-11-3-34-39. 


\section{REVIEWS}

140. Mijuskovic M., Stanojevic I., Milovic N., Cerovic S., Petrovic D., Maksic D., Kovacevic B., Andjelic T., Aleksic P., Terzic B., Djukic M., Vojvodic D. Tissue and urinary KIM-1 relate to tumor characteristics in patients with clear renal cell carcinoma. Int Urol Nephrol 2018; 50(1): 63-70, https://doi. org/10.1007/s11255-017-1724-6.

141. Shalabi A., Abassi Z., Awad H., Halachmi S., Moskovitz B., Kluger Y., Nativ O. Urinary NGAL and KIM-1: potential association with histopathologic features in patients with renal cell carcinoma. Worid J Urol 2013; 31(6): 15411545, https://doi.org/10.1007/s00345-013-1043-1.

142. Gershtein E.S., Kushlinskii N.E. Marker KIM-1 in early diagnostics of renal-cell cancer. Tehnologii zivyh sistem 2019; 16(1): 5-20.

143. Scelo G., Muller D.C., Riboli E., Johansson M., Cross A.J., Vineis P., Tsilidis K.K., Brennan P., Boeing H., Peeters P.H.M., Vermeulen R.C.H., Overvad K., Buenode-Mesquita H.B., Severi G., Perduca V., Kvaskoff M. Trichopoulou A., La Vecchia C., Karakatsani A., Palli D., Sieri S., Panico S., Weiderpass E., Sandanger T.M., Nøst T.H., Agudo A., Quirós J.R., Rodríguez-Barranco M., Chirlaque M.D. Key T.J., Khanna P., Bonventre J.V., Sabbisetti V.S., Bhatt R.S. $\mathrm{KIM}-1$ as a blood-based marker for early detection of kidney cancer: a prospective nested case-control study. Clin Cancer Res 2018; 24(22): 5594-5601, https://doi.org/10.1158/10780432.ccr-18-1496.
144. Sangoi A.R., McKenney J.K., Brooks J.D., Bonventre J.V., Higgins J.P. Evaluation of putative renal cell carcinoma markers PAX-2, PAX-8, and hKIM-1 in germ cell tumors: a tissue microarray study of 100 cases. Appl Immunohistochem Mol Morphol 2012; 20(5): 451-453, https:// doi.org/10.1097/pai.0b013e31824bb404.

145. Kishimoto W., Nishikori M., Arima H., Miyoshi H., Sasaki Y., Kitawaki T., Shirakawa K., Kato T., Imaizumi Y., Ishikawa T., Ohno H., Haga H., Ohshima K., Takaori-Kondo A. Expression of Tim-1 in primary CNS lymphoma. Cancer Med 2016; 5(11): 3235-3245, https://doi.org/10.1002/cam4.930.

146. Liu L., Song Z., Zhao Y., Li C., Wei H., Ma J., Du Y. HAVCR1 expression might be a novel prognostic factor for gastric cancer. PLoS One 2018; 13(11): e0206423, https://doi. org/10.1371/journal.pone.0206423.

147. Xue J., Li Y., Yi J., Jiang H. HAVCR1 Affects the MEK/ ERK pathway in gastric adenocarcinomas and influences tumor progression and patient outcome. Gastroenterol Res Pract 2019; 2019: 6746970, https://doi.org/10.1155/2019/6746970.

148. Zheng X., Xu K., Chen L., Zhou Y., Jiang J. Prognostic value of TIM-1 expression in human non-smallcell lung cancer. J Trans/ Med 2019; 17(1): 178, https://doi. org/10.1186/s12967-019-1931-2.

149. Wang Y., Martin T.A., Jiang W.G. HAVcR-1 expression in human colorectal cancer and its effects on colorectal cancer cells in vitro. Anticancer Res 2013; 33(1): 207-214. 